\title{
Identifikasi Sektor Unggulan Perekonomian Kabupaten Madiun
}

\author{
Dian Pratiwi ${ }^{1}$ Hartirini Warnaningtyas ${ }^{2}$ \\ ${ }^{1,2}$ Fakultas Ekonomi Universitas Merdeka Madiun \\ Email:pratiwidian.new@gmail.com
}

\begin{abstract}
Abstrak
Penelitian ini bertujuan untuk mengidentifikasi sektor-sektor unggulan perekonomian Kabupaten Madiun sehingga dapat memberikan gambaran tentang kondisi pertumbuhan ekonomi serta menjadi bahan pertimbangan dalam perencanaan pembangunan di Kabupaten Madiun. Data yang digunakan adalah data sekunder yang bersifat time series yang berasal dari Produk Domestik Regional Bruto Kabupaten Madiun tahun 2010-2013. Alat analisis yang digunakan dalam penelitian ini adalah analisis tipologi Klassen dan analisis Shift share. Dari analisis tipologi Klassen dapat disimpulkan bahwa sektor yang maju dan tumbuh dengan pesat adalah sektor pertanian, perdagangan, hotel dan restoran, dan jasa-jasa. Sedangkan dengan menggunakan analisis Shift share, laju pertumbuhan dan Pertumbuhan Proporsional (PP) tertinggi terdapat pada sektor pengangkutan dan komunikasi. Sektor dengan Pertumbuhan Pangsa Wilayah $(P P W)>0$ dapat dikategorikan memiliki daya saing lebih baik dibanding wilayah lain yaitu sektor listrik, gas dan air bersih.

Kata kunci: Sektor unggulan, tipologi Klassen, Shift share
\end{abstract}

\section{The Identification of Economic Leading Sectors of Madiun Regency}

\begin{abstract}
This research aims to identify the economic leading sectors of Madiun regency in order to give an idea of the condition of economic growth as well as being a material consideration in development planning at the district of Madiun. The used data are secondary data of time series which are derived from the Produk Domestik Regional Bruto(PDRB) of Madiun regency at period 2010-2013. The analytical tool of this research is Klassen typology analysis and shift share analysis. By this Klassen typology analysis can be concluded that the advanced sector and rapidly growing sector are agriculture, trades, hotels, and restaurant and services. Whereas by using shift share analysis, the highest growth rate and proportional shift is transportation and communication sector. The sectors that have competitive power among other sectors with Differential Shift Component $>0$ is electricity, gas and water utilities.
\end{abstract}

Keywords: Leading sectors, Klassen typology, Shift share

\section{PENDAHULUAN}

Diberlakukannya MEA(Masyarakat Ekonomi ASEAN) merupakan hasil dari kesepakatan integrasi ekonomi yang dicapai dalam ASEAN Community yang memuat: ASEAN Security Community (ASC), AEC dan ASEAN Socio-Cultural Community (ASCC) (Sukarwo, 2015). MEA menjadi pasar tunggal di mana terjadi arus barang, jasa, investasi, dan tenaga terampil serta arus modal yang bebas di antara negara-negara ASEAN. Semua kegiatan ekonomi dan sosial masyarakat domestik telah terintegrasi dengan sistem internasional yang lebih luas. Hal ini menjadi tantangan sekaligus peluang jika dilihat dari 
sisi ekonomi. Integrasi Ekonomi MEA diyakini akan meningkatkan pertumbuhan ekonomi negara-negara di ASEAN termasuk Indonesia.

Dengan diberlakukannya MEA, maka pemerintah serta masyarakat dituntut lebih kreatif sehingga memiliki daya saing yang lebih unggul. Daya saing di tiap-tiap daerah harus dioptimalkan dan ditonjolkan sehingga mampu bertahan ditengah gempuran berbagai komoditi luar negeri yang masuk di pasar domestik.

Salah satu indikator kekuatan daya saing suatu daerah dapat dilihat dari kemampuannya dalam meningkatkan pendapatan regional, hal tersebut bisa teramati dengan mengacu pada Produk Domestik Regional Bruto (PDRB). Keberhasilan pembangunan suatu wilayah ditentukan oleh kemampuan masing-masing sektor pembentuk PDRB dalam memacu pertumbuhannya. Pembangunan ekonomi daerah adalah suatu proses di mana pemerintah daerah dan masyarakatnya mengelola sumber daya yang ada dan membentuk suatu pola kemitraan antara pemerintah daerah dan sektor swasta untuk menciptakan suatu lapangan kerja baru, serta merangsang perkembangan kegiatan ekonomi dalam wilayah tersebut (Arsyad, 2005).

Kabupaten Madiun sebagai salah satu pelaksana otonomi daerah menunjukkan keseriusan dalam meningkatkan pembangunan daerah. Sektor-sektor yang menjadi unggulan menjadi fokus penopang perekonomian daerah. Terkait dengan kebijakan anggaran, penentuan prioritas kebijakan tentang pengeluaran daerah merupakan hal yang penting. Penentuan prioritas kebijakan tersebut dapat diwujudkan salah satunya dengan menentukan sektorsektor prioritas atau unggulan. Lebih jauh, penentuan prioritas tidak hanya dilakukan pada tingkat sektoral saja, tetapi juga pada tingkat subsektor, usaha, bahkan tingkat komoditi yang layak untuk dikembangkan sesuai dengan kebutuhan dan potensi yang ada.

Penelitian ini dilakukan untuk mengidentifikasi bagaimana klasifikasi pertumbuhan sektor perekonomian Kabupaten Madiun serta untuk mengetahui bagaimana pola pergeseran sektor perekonomian sehingga dapat diketahui sektor-sektor apa saja yang menjadi unggulan dan dapat diprioritaskan di Kabupaten Madiun.

\section{METODE}

Data yang disajikan oleh Produk Domestik Regional Bruto (PDRB) dapat memberikan berbagai macam informasi yang tentunya sangat bermanfaat dalam penentuan kebijakan daerah. Untuk mengidentifikasi sektor yang dapat dijadikan prioritas sebagai sektor unggulan dapat dilakukan dengan alat bantu berupa analisis Tipologi Klassen dan analisis Shift share. Dengan dua alat analisis tersebut, kita dapat mengetahui sektor-sektor apa saja yang tumbuh dan berkembang dan dapat diunggulkan dari PDRB Kabupaten Madiun berdasarkan data time series.

1. Analisis Tipologi Klassen digunakan untuk mengidentifikasi posisi sektor perekonomian Kabupaten Madiun dengan memperhatikan sektor perekonomian Provinsi Jawa Timur sebagai daerah referensi. Analisis Tipologi Klassen menghasilkan empat klasifikasi sektor dengan karakteristik yang berbeda sebagai berikut (Sjafrizal, 2008:180):

a. Sektor yang maju dan tumbuh dengan pesat (developed sector) (Kuadran I). Kuadran ini merupakan kuadran yang laju pertumbuhan sektor tertentu dalam PDRB (si) lebih besar dibandingkan laju pertumbuhan sektor tersebut dalam PDRB daerah yang menjadi referensi (s) dan memiliki nilai kontribusi sektor terhadap PDRB (ski) yang lebih besar dibandingkan kontribusi sektor tersebut terhadap PDRB daerah yang menjadi referensi (sk).

b. Sektor maju tapi tertekan (stagnant sector) (Kuadran II). Kuadran ini merupakan kuadran yang laju pertumbuhan sektor tertentu dalam PDRB (si) lebih kecil dibandingkan laju pertumbuhan sektor tersebut dalam PDRB daerah yang menjadi 
referensi (s), tetapi memiliki nilai kontribusi sektor terhadap PDRB (ski) yang lebih besar dibandingkan kontribusi sektor tersebut terhadap PDRB daerah yang menjadi referensi (sk).

c. Sektor potensial atau masih dapat berkembang (developing sector) (Kuadran III). Kuadran ini merupakan kuadran yang laju pertumbuhan sektor tertentu dalam PDRB (si) lebih besar dibandingkan laju pertumbuhan sektor tersebut dalam PDRB daerah yang menjadi referensi (s), tetapi memiliki nilai kontribusi sektor terhadap PDRB (ski) yang lebih kecil dibandingkan kontribusi sektor tersebut terhadap PDRB daerah yang menjadi referensi (sk).

d. Sektor relatif tertinggal (underdeveloped sector) (Kuadran IV). Kuadran ini merupakan kuadran yang laju pertumbuhan sektor tertentu dalam PDRB (si) lebih

kecil dibandingkan laju pertumbuhan sektor tersebut dalam PDRB daerah yang menjadi referensi (s) dan sekaligus memiliki nilai kontribusi sektor terhadap PDRB $\left(\mathrm{ski}_{\mathrm{i}}\right.$ yang lebih kecil dibandingkan kontribusi sektor tersebut terhadap PDRB daerah yang menjadi referensi (sk).

2. Analisis Shift Share pertama kali diperkenalkan oleh Perloff et all pada tahun 1960. Analisis Shift Share adalah salah satu alat analisis yang digunakan untuk mengindentifikasi sumber pertumbuhan ekonomi baik dari sisi pendapatan maupun dari sisi tenaga kerja pada suatu wilayah tertentu. Keunggulan utama dari analisis Shift Share adalah dapat melihat perkembangan produksi atau kesempatan kerja di suatu wilayah hanya dengan menggunakan 2 titik waktu data. Data yang digunakan dalam analisis Shift Share dapat berupa data PDRB, PDB dan penyerapan tenaga kerja di masing-masing sektor. Terdapat 3 komponen utama dalam analisis Shift Share (Budiharsono, 2001). Ketiga komponen pertumbuhan wilayah tersebut adalah komponen pertumbuhan nasional/propinsi/kabupaten $(\mathrm{PN})$, komponen pertumbuhan regional dan komponen pertumbuhan pangsa wilayah (PPW).

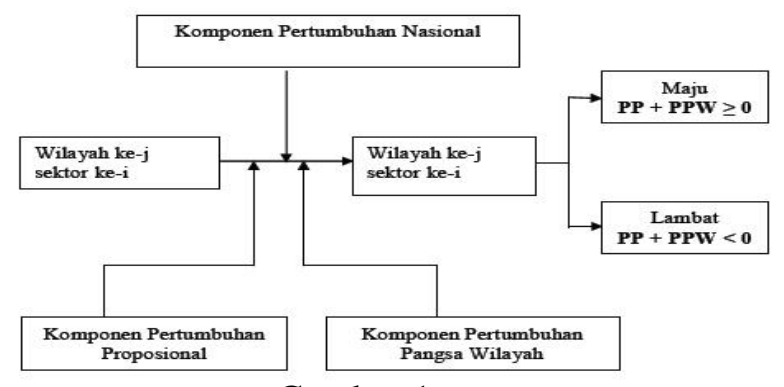

Gambar 1

Model Analisis Shift Share (Budiharsono, 2001)

PEMBAHASAN

1. Analisis Tipologi Klassen

Dengan menggunakan alat analisis tipologi Klassen sektor perekonomian Kabupaten Madiun dapat diklasifikasikan sebagaimana paparan dalam gambar 2 di bawah ini:

\begin{tabular}{|c|c|}
\hline $\begin{array}{l}\text { KUADRAN I } \\
\text { Sektor Yang Maju Dan Tumbuh Dengan Pesat } \\
\text { si }>\text { s dan ski }>\text { sk } \\
\bullet \text { Pertanian } \\
\text { Jasa-jasa } \\
\text { Perdagangan, hotel dan } \\
\bullet \text { restoran }\end{array}$ & $\begin{array}{c}\text { KUADRAN II } \\
\text { Sektor maju tapi tertekan (stagnant sector) } \\
\text { si }<\text { s dan ski }>\text { sk } \\
\bullet \quad \text { Bangunan }\end{array}$ \\
\hline $\begin{array}{c}\text { KUADRAN III } \\
\text { Sektor potensial atau masih dapat } \\
\text { berkembang (developing sector) } \\
\text { si > s dan ski < sk } \\
\text { - } \quad \text { Listrik, gas dan air minum } \\
\text { Pengangkutan dan komunikasi }\end{array}$ & $\begin{array}{c}\text { KUADRAN IV } \\
\text { Sektor relatif tertinggal (underdeveloped sector) } \\
\text { si }<\mathrm{s} \text { dan ski }<\text { sk } \\
\text { Pertambangan dan galian } \\
\text { - } \quad \text { Industry pengolahan } \\
\text { Keuangan, persewaan dan jasa } \\
\text { perusahaan. }\end{array}$ \\
\hline
\end{tabular}


Gambar 2

Klasifikasi Sektor PDRB Kabupaten Madiun Tahun 2010-2013

berdasarkan tipologi Klassen

Berdasarkan hasil analisis pada gambar diatas, dapat diketahui bahwa terdapat tiga sektor yang termasuk dalam kategori sektor maju dan tumbuh dengan pesat, yaitu sektor pertanian, sektor perdagangan hotel dan restoran dan sektor jasa-jasa. Sektor-sektor tersebut memberikan kontribusi rata-rata terbesar terhadap PDRB masing-masing sebesar $35,03 \%$, 33,86\% dan 16,67\%. Kondisi ini menunjukkan bahwa sektor pertanian merupakan sektor yang dominan dan menjadi sektor penyumbang terbesar terhadap PDRB.

\section{Analisis Shift Share}

Tabel 1

Perubahan PDRB Kabupaten Madiun dan Provinsi Jawa Timur Menurut Sektor Perekonomian Atas Dasar Harga Konstan Tahun 2010-2013 (Juta

Rupiah)

\begin{tabular}{|c|c|c|c|c|c|c|c|c|}
\hline \multirow{2}{*}{$\begin{array}{c}\mathrm{Se} \\
\text { kto } \\
\mathrm{r}\end{array}$} & \multicolumn{2}{|c|}{ PDRB Kabupaten Madiun } & \multicolumn{2}{|c|}{$\begin{array}{l}\text { Perubahan PDRB } \\
\text { Kabupaten Madiun }\end{array}$} & \multicolumn{2}{|c|}{ PDRB Provinsi Jawa Timur } & \multicolumn{2}{|c|}{$\begin{array}{c}\text { Perubahan PDRB Provinsi } \\
\text { Jawa Timur }\end{array}$} \\
\hline & 2010 & 2013 & Perubahan & $\%$ & 2010 & 2013 & Perubahan & $\%$ \\
\hline 1 & $1.127 .800,68$ & $1.238 .749,24$ & $110.948,56$ & 9,84 & $51.329 .548,83$ & $55.330 .095,90$ & $4.000 .54, .07$ & 7,79 \\
\hline 2 & $15.420,59$ & $16.201,12$ & 780,53 & 5,06 & $7.757 .319,82$ & $8.697 .627,56$ & $940.307,74$ & 12,12 \\
\hline 4 & $28.615,95$ & $36.111,12$ & $7.495,17$ & 26,19 & $4.642 .081,81$ & $5.486 .499,10$ & $844.417,28$ & 18,19 \\
\hline 5 & $99.624,69$ & $125.602,31$ & $25.977,62$ & 26,08 & $10.992 .599,76$ & $14.006 .020,59$ & $3.013 .420,83$ & 27,41 \\
\hline 6 & $992.622,23$ & $1.306 .358,16$ & $313.735,93$ & 31,61 & $106.229 .112,97$ & $139.431 .307,45$ & $33.202 .194,48$ & 31,26 \\
\hline $\begin{array}{l}\text { jm } \\
\text { lh }\end{array}$ & 3.071.607,54 & $3.700 .327,29$ & $628.719,75$ & 20,47 & $342.280 .764,89$ & 419.428.445,69 & $77.147 .680,80$ & 22.54 \\
\hline
\end{tabular}

Sumber : BPS Kabupaten Madiun Tahun 2010-2013, diolah

Keterangan : 1 = Sektor Pertanian; 2 = Sektor Pertambangan dan Penggalian; 3 = Sektor Industri Pengolahan; 4 = Sektor Listrik, Gas dan Air bersih; 5 = Sektor Bangunan; $6=$ Sektor Perdagangan, Hotel dan Restoran; 7 = Sektor Pengangkutan dan Komunikasi; 8 =Sektor Keuangan. Persewaan dan Jasa Perusahaan; 9 =Sektor Jasa-jasa.

Dengan menggunakan analisis Shift share secara umum laju pertumbuhan ekonomi Kabupaten Madiun mengalami pertumbuhan yang positif yaitu sebesar 20,47\% dengan tahun 2010 sebagai tahun dasar dan tahun 2013 sebagai tahun akhir penelitian. Namun laju pertumbuhan Kabupaten Madiun tersebut masih lebih rendah dibanding laju pertumbuhan ekonomi Provinsi Jawa Timur dengan selisih sebesar 2,07\%. Perekonomian Kabupaten Madiun menunjukan perkembangan yang positif. Pertumbuhan tertinggi dari Kabupaten Madiun terdapat pada sektor pengangkutan dan komunikasi yaitu sebesar $32,75 \%$.

Pertumbuhan sektor-sektor perekonomian di Kabupaten Madiun dipengaruhi oleh tiga komponen pertumbuhan wilayah yaitu Komponen Pertumbuhan Provinsi (KPP), Pertumbuhan Proporsional (PP), dan Pertumbuhan Pangsa Wilayah (PPW).

Pertumbuhan regional/provinsi digunakan untuk menjelaskan kebijakan ekonomi regional (Jawa Timur) yang mempengaruhi perekonomian ditingkat kabupaten/kota, dalam hal ini adalah Kabupaten Madiun.Berdasarkan Pertumbuhan Proporsional (PP) sektor-sektor 
ekonomi di Kabupaten Madiun ada yang memberikan nilai kontribusi secara positif maupun negatif. Sektor yang memiliki pertumbuhan proporsional yang positif jika PP $>0$, yaitu sektor bangunan sebesar 4,41\%, sektor perdagangan, hotel dan restoran sebesar $8,25 \%$, sektor pengangkutan dan komunikasi sebesar 11,94 \%, sektor keuangan, persewaan dan jasa perusahaan sebesar $2,70 \%$. Artinya keempat sektor tersebut memiliki laju pertumbuhan yang cepat.

Tabel 2

Komponen Pertumbuhan Wilayah Kab. Madiun (Juta Rp)

\begin{tabular}{|c|c|c|c|c|c|}
\hline \multirow{2}{*}{ Sektor } & KPP & PP & Persen & PPW & Persen \\
\hline & $(\mathbf{R a}) * \mathbf{Y} \mathbf{i j}$ & $\begin{array}{c}\text { (Ri-Ra) } \\
\text { Yij }\end{array}$ & $\begin{array}{c}(\mathbf{P P}) / \mathrm{Yij} \text { * } \\
100 \%\end{array}$ & $\begin{array}{c}(\mathbf{r i}-\mathbf{R i}) \\
\mathbf{Y i j}\end{array}$ & $\begin{array}{c}(\mathbf{P P W}) / \mathrm{Yij} \text { * } \\
100 \%\end{array}$ \\
\hline 1 & $259.394,16$ & $-171.495,08$ & $-15,20615189$ & $23.049,49$ & 2,043755463 \\
\hline 2 & $3.546,74$ & $-1.677,52$ & $-10,87844558$ & $-1.088,69$ & $-7,059945238$ \\
\hline 3 & $22.767,86$ & $-3.862,45$ & $-3,901835728$ & $-2.587,17$ & $-2,613553446$ \\
\hline 4 & $6.581,67$ & $-1.376,29$ & $-4,809513144$ & $2.289,79$ & 8,001794022 \\
\hline 5 & $22.913,68$ & $4.396,61$ & 4,413177041 & $-1.332,67$ & $-1,337693142$ \\
\hline 6 & $228.303,11$ & $81.943,63$ & 8,255268493 & $3.489,19$ & 0,351512065 \\
\hline 7 & $23.301,74$ & $12.095,08$ & 11,938463 & $-2.221,48$ & $-2,192717712$ \\
\hline 8 & $22.082,32$ & $2.596,71$ & 2,704624406 & $-6.662,83$ & $-6,939721675$ \\
\hline 9 & $117.578,46$ & $-34.423,58$ & $-6,733736513$ & $19.117,29$ & 3,739610411 \\
\hline TOTAL & $706.469,73$ & $-111.802,89$ & $-14,22$ & $34.052,90$ & $-6,01$ \\
\hline
\end{tabular}

Sumber: BPS Kabupaten Madiun Tahun 2010 dan 2013, diolah

Keterangan:1=Pertanian; 2=Pertambangan dan Penggalian; 3=Industri Pengolahan; 4=Listrik, Gas dan Air Bersih; 5=Kontruksi; 6=Perdagangan, Hotel dan Restoran; 7=Pengangkutan dan Komunikasi; 8=Keuangan, Persewaan dan Jasa Perusahaan; 9=Jasajasa. KPP $=$ Komponen pertumbuhan propinsi sektor i untuk wilayah j, PP $=$ Komponen pertumbuhan proporsional sektor $\mathrm{i}$ untuk wilayah $\mathrm{j}$ dan $\mathrm{PPW}=$ Komponen pertumbuhan pangsa wilayah sektor $\mathrm{i}$ untuk wilayah $\mathrm{j}$. Yij = Produksi dari sektor $\mathrm{i}$ pada wilayah kabupaten (tahun dasar analisis). $\mathrm{Ra}=0,23$ untuk mengambarkan satuan wilayah

Sektor yang mengalami penurunan kontribusi terhadap $\mathrm{PDRB}$ jika $\mathrm{PP}<0$, yaitu sektor pertanian $(-171,49 \%)$, sektor pertambangan dan penggalian $(-1,68 \%)$, sektor industri pengolahan $(-3,86 \%)$, sektor listrik, gas dan air bersih $(-1,37 \%)$, dan sektor jasa-jasa ($34,42)$. Artinya, kelima sektor tersebut memiliki pertumbuhan ekonomi yang lambat.

Selanjutnya, untuk mengetahui komponen pertumbuhan wilayah lain adalah Pertumbuhan Pangsa Wilayah (PPW). Komponen PPW timbul karena peningkatan atau penurunan PDRB atau kesempatan kerja dalam suatu wilayah dibandingkan dengan wilayah lainnya. Jika PPW >0 maka sektor yang bersangkutan memiliki daya saing yang baik bila dibandingkan dengan wilayah lainnya yang ada di Provinsi Jawa Timur. Adapun sektor yang memiliki daya saing yang baik adalah sektor pertanian sebesar 2,04 \%, sektor listrik, gas dan air bersih sebesar $8 \%$, sektor perdagangan, hotel dan restoran sebesar $0,35 \%$, dan sektor jasa-jasa 3,74\%. Sedangkan sektor yang memiliki daya saing yang tidak baik jika PPW $<0$ adalah sektor pertambangan dan penggalian $(-7,06 \%)$, sektor industri pengolahan $(-2,61 \%)$, sektor bangunan $(-1,38 \%)$, sektor pengangkutan dan komunikasi $(-2,20 \%)$, serta sektor keuangan, persewaan dan jasa perusahaan $(-6,94 \%)$.

Pergeseran bersih diperoleh dari hasil penjumlahan antara Pertumbuhan Proporsional (PP) dan Pertumbuhan Pangsa Wilayah (PPW) di setiap sektor perekonomian. Apabila PB $>0$, maka pertumbuhan sektor perekonomian Kabupaten Madiun termasuk ke dalam kelompok yang progresif (maju). Sedangkan PB < 0, artinya sektor perekonomian Kabupaten Madiun termasuk kelompok yang lamban. 
Tabel 3

Pergeseran Bersih Sektor Perekonomian Kabupaten Madiun

\begin{tabular}{|l|l|r|c|}
\hline \multirow{2}{*}{ No. Sektor } & \multicolumn{2}{|c|}{ Pergeseran Bersih (PB) } \\
\cline { 3 - 4 } & & \multicolumn{1}{|c|}{ Rp (juta) } & \multicolumn{1}{c|}{ Persen } \\
\hline 1 & Pertanian & $-148.445,60$ & $-13,16$ \\
\hline 2 & Pertambangan dan Penggalian & $-2.766,21$ & $-17,93$ \\
\hline 3 & Industri Pengolahan & $-6.449,63$ & $-6,51$ \\
\hline 4 & Listrik, Gas dan Air Bersih & 913,50 & 3,19 \\
\hline 5 & Bangunan & $3.063,94$ & 3,07 \\
\hline 6 & Perdagangan, Hotel dan Restoran & $85.432,82$ & 8,60 \\
\hline 7 & Pengangkutan dan Komunikasi & $9.873,60$ & 9,74 \\
\hline 8 & Keuangan, Persewaan dan Jasa Perusahaan & $-4.066,12$ & $-4,23$ \\
\hline 9 & Jasa-jasa & $-15.306,29$ & $-2,99$ \\
\hline & Total & $-77.749,98$ & $-20,23$ \\
\hline
\end{tabular}

Sumber : BPS Kabupaten Madiun, diolah

Sektor yang memiliki PB>0 adalah sektor listrik, gas dan air bersih sebesar 3,19\%, sektor bangunan sebesar 3,07\%, sektor perdagangan, hotel dan restoran sebesar 8,61\%, serta sektor pengangkutan dan komunikasi sebesar 9,74\%. Sedangkan sektor yang memiliki $\mathrm{PB}<0$ adalah sektor pertanian $(-13,16 \%)$, sektor pertambangan dan penggalian $(-17,94 \%)$, sektor industri pengolahan $(-6,51 \%)$, sektor keuangan, persewaan dan jasa perusahaan ($4,23 \%)$, serta sektor jasa-jasa $(-2,99 \%)$.

\section{KESIMPULAN}

Sektor-sektor perekonomian Kabupaten Madiun dapat dikategorikan sebagai sektor unggulan berdasarkaan kriteria dua alat analisis yaitu analisis tipologi Klassen dan analisis Shift Share. Berdasarkan analisis tipologi Klassen, sektor yang maju dan tumbuh dengan pesat adalah sektor pertanian, perdagangan, hotel dan restoran dan sektor jasa-jasa. Sedangkan menurut analisis Shift Share, sektor yang memiliki pertumbuhan tertinggi adalah sektor pengangkutan dan komunikasi walaupun jika dibandingkan dengan daerah lain, sektor tersebut masih belum memiliki daya saing yang lebih unggul. Pemerintah daerah terus berupaya sejalan dengan yang dilakukan oleh pemerintah Provinsi Jawa Timur dalam meningkatkan daya saing wilayahnya dengan peningkatan kualitas kemantapan jalan dan semakin kuatnya konektivitas antarmoda antarwilayah di Jawa Timur.

\section{DAFTAR PUSTAKA}

Arsyad, Lincolin, 2005. Pengantar Perencanaan dan Pembangunan Ekonomi Daerah. BPFE. Yogyakarta.

Badan Pusat Statistik. 2013. Kabupaten Madiun Dalam Angka. BPS Kabupaten Madiun. Madiun.

Badan Pusat Statistik. 2013. Propinsi Jawa Timur Dalam Angka. BPS Propinsi Jawa Timur. Surabaya.

Budiharsono, S. 2001. Teknik Pengembangan Wilayah Pesisir dan Lautan. Pradnya Paramita. Jakarta.

Sjafrizal, 2008. Ekonomi Regional, Teori dan Aplikasi, Baduose Media, Cetakan Pertama, Padang.

Soekarwo, dkk. 2015. Pintu Gerbang MEA 2015 Harus Dibuka. Prenadamedia Group. Cetakan ketiga. Jakarta. 